\title{
Floristic diversity of Dagestan florocoenotypes
}

\author{
Ramazan Murtazaliev* \\ Dagestan Federal Research Center RAS, 367000 Makhachkala, Russia
}

\begin{abstract}
The paper provides information on the floristic diversity of the florocenotypes of Dagestan 43 florocenotypes and 3 types of plant communities in anthropogenically altered habitats which are combined into three groups have been identified. It is registered that the most floristically rich florocoenotypes in the lowlands and in the zone of low foothills are shrub steppes (498 species), xerophilous forests and light forests of the Mediterranean type (462), forbs dry steppes of foothills (431) and herbcereal dry meadows of foothills (334), and in the mountain areas: polyurus vegetation (499 species), steppe after forest meadows (381), mixed deciduous forests (362), subalpine meadows (312) and xerophytic lithophyton with 310 species. Floristically poor florocenotypes are aquatic vegetation of mountain lakes with 14 species, vegetation of water bodies (53 species), precaspian floodplains (67) and precaspian curtain meadows (78 species). During the analysis of the floristic similarity, the florocoenotypes were combined into several clades, which we conditionally distinguished into the following groups: desert, hydrophytic, mesophytic, steppe, and arid.
\end{abstract}

During investigation of regional floras, an analysis of the distribution of species by habitat, types of vegetation or biocenoses is often carried out, what, on the one hand, reflects the diversity of plant communities of the territory explored, on the other hand, their species richness. In our opinion, the best choice in such analyzes is to identificate florocoenotypes, as an intermediate type between a larger rank - vegetation, and smaller subdivisions like formation or association. We understand the florocoenotype as a set of formations, which edificators develop under the same environmental conditions for a long historical time. It should be understood that edificators in florocenotypes may not necessarily act as dominants. For example, in the bushy caspian deserts, where the role of edificators is played by the species Tamarix and Elaeagnus, in the spring period ephemerals can prevail over them in almost all respects. The main role of edificators in florocenotypes is environment-forming, creating conditions for the development of other species.

In recent years, the problem of classifying habitats paid much attention, there are many publications, summarizing the data, as well as pan-European [1-3], and regional importance [4-7].

In this regard, we carried out work on the identification of florocenotypes for the territory of Dagestan, which we conventionally combined into three groups. Table 1 shows the identified florocenotypes with their species diversity. Note that 3442 species are currently given for Dagestan, what was taken into account in this analysis.

\footnotetext{
*Corresponding author: murtazaliev.ra@yandex.ru
} 
On the lowlands and in the zone of the low foothills, the most floristically rich florocenotypes are shrub steppes (498 species), xerophytic forests and light forests of the Mediterranean type (462), forbs dry steppes of the foothills (431), and herb-cereal dry meadows of the foothills (334). Basically, the core of all these types is made up of the same species. In precaspian floodplains, vegetation of water bodies and precaspian curtain meadows, the smallest number of species is noted, there are 50-80 species here.

Table 1. Florocenotypes of Dagestan and their species diversity

\begin{tabular}{|c|c|c|}
\hline $\begin{array}{c}\text { Conv. } \\
\text { designation }\end{array}$ & Florocenotypes & $\begin{array}{c}\text { Number of } \\
\text { species }\end{array}$ \\
\hline \multicolumn{3}{|c|}{ Florocenotypes, predominantly found in lowlands and in } \\
\hline A.1. & Littoral vegetation & 244 \\
\hline A.2. & Precaspian floodplains & 67 \\
\hline A.3. & Vegetation of water bodies & 53 \\
\hline A.4. & Deserted steppes & 227 \\
\hline A.5. & Psammophyton of the Turanian type & 237 \\
\hline A. 6. & Semi-shrub deserts of the Turanian type & 150 \\
\hline A.7. & Halophyton & 127 \\
\hline A.8. & Precaspian shrub deserts & 141 \\
\hline A.9. & Floodplain forests of tugai type & 183 \\
\hline A.10. & Floodplain forests of the Hyrcanian type & 203 \\
\hline A. 11 . & Lowland forests & 161 \\
\hline A.12. & Foothill tall grass & 244 \\
\hline A.13. & Coarse-grained savannoids & 161 \\
\hline A.14. & Precaspian curtain meadows & 78 \\
\hline A.15. & Wet lowland meadows & 197 \\
\hline A.16. & Herbal swamps of the ancient Mediterranean type & 146 \\
\hline A.17. & Forbs dry steppes of the foothills & 431 \\
\hline A.18. & Clayed deserts of the foothills & 230 \\
\hline A.19. & Shrub steppes & 498 \\
\hline A.20. & Xerophilous forests and light forests of the Mediterranean type & 462 \\
\hline A.21. & Herb-cereal dry meadows of the foothills & 334 \\
\hline A.22. & Juniper trees & 247 \\
\hline \multicolumn{3}{|c|}{$\begin{array}{l}\text { B. Florocenotypes, predominantly found in the upper zone of the foothills, } \\
\text { as well as in the middle and upper mountain belts }\end{array}$} \\
\hline B.1. & Mountain andropogon steppes & 114 \\
\hline B.2. & Dagestan polydominant phryganoids & 145 \\
\hline B.3. & Tragacants & 169 \\
\hline B.4. & Polyurus vegetation & 499 \\
\hline B.5. & Xerophytic lithophyton & 310 \\
\hline B.6. & Xerophytic glareophyton & 276 \\
\hline B.7. & Steppe after forest meadows & 381 \\
\hline
\end{tabular}




\begin{tabular}{|c|l|c|}
\hline B.8. & Mesophitic mountain steppes & 241 \\
\hline B.9. & Pine forests & 120 \\
\hline B.10. & Mixed deciduous forests & 362 \\
\hline B.11. & Mountain small-leaved forests & 279 \\
\hline B.12. & Mountain bogs and swampy meadows & 204 \\
\hline B.13. & Aquatic vegetation of mountain lakes & 14 \\
\hline B.14. & Mesophytic shale lithophyton & 227 \\
\hline B.15. & Subalpine meadows & 312 \\
\hline B.16. & Subalpine tall grass & 158 \\
\hline B.17. & Alpine meadows & 195 \\
\hline B.18. & Rhodorets & 80 \\
\hline B.19. & Alpine lithophyton & 102 \\
\hline B.20. & Alpine glareophyton & 156 \\
\hline C. Intrazonal vegetation and plant communities of anthropogenically modified habitats \\
\hline C.1. & Arable land, gardens, abandoned fields & 207 \\
\hline C.2. & Ruderal vegetation & 347 \\
\hline C.3. & Vegetation of overburdened pastures & 178 \\
\hline C.4. & Pebble vegetation & 118 \\
\hline
\end{tabular}

In the middle and upper mountain belts, according to the number of species, polyurus vegetation are distinguished, which for almost 500 plant species have been identified, after that steppe after forest meadows follow with 381 species, mixed deciduous forests $(362$ species), subalpine meadows (312) and xerophytic lithophyton with 310 species. From 200 to 280 species were recorded for mountain small-leaved forests (279 species), xerophytic glareophyton (276), mesophytic mountain steppes (241), mesophytic shale lithophyton (227) and for mountain bogs and swampy meadows (204 species). In mountain areas aquatic vegetation of mountain lakes are floristically poor florocenotypes, only 14 species of which are registered (Myriophyllum verticillatum L., Callitriche verna L., Potamogeton alpinus Balb. etc.).

We have selected plant communities of anthropogenically modified habitats into a separate group. The maximum number of species among them (347) was recorded in ruderal areas, as well as in arable land, gardens, abandoned fields (207 species). We identified pebble vegetation as an introzonal type, where 118 species were identified. Representative species of this type is Myricaria bracteata Royle, Salix xerophila Floderus, Cladochaeta candissima (M. Bieb.) DC., Trachomitum sarmatiense Woodson and others.

During analysis of the species of similarities florocenotypes grouped into 4 large clades (fig. 1). In the first clade, the floracenotypes of the "desert group" were united: florocenotypes of deserted steppes, littoral vegetation, psammophyton of the Turanian type, semi-shrub deserts of the Turanian type, clayed deserts of the foothills, etc. 


\section{florocenotypes}

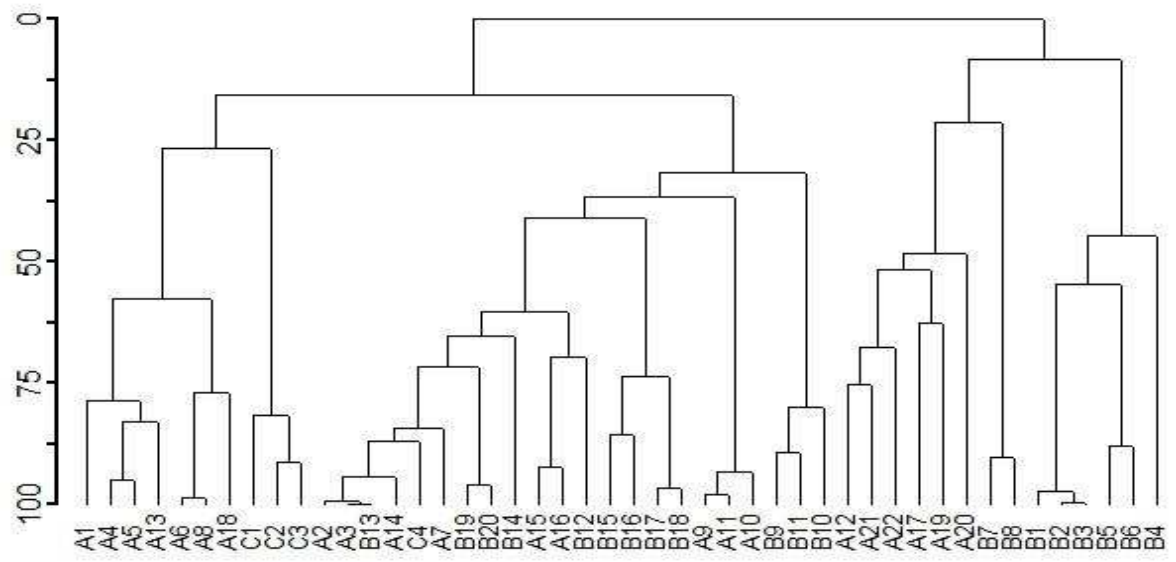

Fig. 1. Clustergram of the similarity of florocoenotypes by species composition (explanation of symbols is given in table 1).

Here, the plant communities of anthropogenically modified habitats were united as a separate group.

The second large clade was formed by the "hydrophytic" florocenotypes (Precaspian floodplains, vegetation of the water bodies, Precaspian curtain meadows, aquatic vegetation of mountain lakes, pebble vegetation, etc.) and "mesophytic" (florocenotypes of meadow and forest vegetation) groups. Third clade consists of florocenotypes of "steppe" group: foothill tall grass, forbs dry steppes of the foothills, shrub steppes, xerophilous forests and light forests of the Mediterranean type, juniper forests, steppe after forest meadows and mesophytic mountain steppes.

The fourth clade unites the floracenotypes of the "arid" group, which are mostly found in the middle mountain zone under conditions of moisture deficiency: mountain andropogon steppes, dagestan polydominant phryganoids, tragacanths, polyurus vegetation, xerophytic lithophyton and xerophytic glareophyton.

\section{Referensces}

1. P. Devillers, J. Devillers-Terschuren, J.-P. Ledant, CORINE biotopes manual. 2. (Luxembourg, 1991)

2. P. Devillers, J. Devillers-Terschuren, A classification of Palearctic habitats. 78 (Strasbourg, 1996)

3. C. E. Davies, D. Moss, M. O. Hill, EUNIS Habitat classification revised (2004)

4. G. N. Ogureeva, South of Russia: ecology, development 11 (2016)

5. G. M. Fayvush, A. S. Alexanjan, Habitats of Armenia (2016)

6. S. A. Belonovskaya, Bulletin of the Tver State Univ. Series: Biology and Ecology 2 (2017)

7. R. V. Kamelin, Bot. Jour. 102 (2017) 